IZA DP No. 7748

How Do Immigrants from Taiwan Fare in the U.S. Labor Market?

Carl Lin

November 2013 


\title{
How Do Immigrants from Taiwan Fare in the U.S. Labor Market?
}

\author{
Carl Lin \\ Beijing Normal University \\ and IZA
}

Discussion Paper No. 7748

November 2013

\author{
IZA \\ P.O. Box 7240 \\ 53072 Bonn \\ Germany \\ Phone: +49-228-3894-0 \\ Fax: +49-228-3894-180 \\ E-mail: iza@iza.org
}

Any opinions expressed here are those of the author(s) and not those of IZA. Research published in this series may include views on policy, but the institute itself takes no institutional policy positions. The IZA research network is committed to the IZA Guiding Principles of Research Integrity.

The Institute for the Study of Labor (IZA) in Bonn is a local and virtual international research center and a place of communication between science, politics and business. IZA is an independent nonprofit organization supported by Deutsche Post Foundation. The center is associated with the University of Bonn and offers a stimulating research environment through its international network, workshops and conferences, data service, project support, research visits and doctoral program. IZA engages in (i) original and internationally competitive research in all fields of labor economics, (ii) development of policy concepts, and (iii) dissemination of research results and concepts to the interested public.

IZA Discussion Papers often represent preliminary work and are circulated to encourage discussion. Citation of such a paper should account for its provisional character. A revised version may be available directly from the author. 
IZA Discussion Paper No. 7748

November 2013

\section{ABSTRACT}

\section{How Do Immigrants from Taiwan Fare in the U.S. Labor Market?}

This paper presents evidence that since 1980, relative to other immigrants, the earnings of Taiwanese immigrants have grown rapidly as they assimilate into the U.S. economy. Our estimates indicate that the rising returns to education, pre-migration experience and hours worked per week play pivotal roles for their relatively successful economic assimilation. We investigate the earnings differentials, finding that the growing gap can be largely explained by differences in individual's endowments - of which more than two-thirds can be solely attributed to education. We show that more recently arrival cohorts of Taiwanese immigrants have earned more than the older ones since 1980.

JEL Classification: J31, J61

Keywords: Taiwan, immigration, economic assimilation, earnings differential, Oaxaca-Blinder decomposition

Corresponding author:

Carl Lin

Beijing Normal University

No.19 Xinjiekou Outer St.

Haidian Dist.

Beijing

P.R. China

E-mail: csmlin@bnu.edu.cn 


\section{Introduction}

As Taiwan experienced remarkable economic growth in the 1970s and 1980s, migration from Taiwan to the U.S. began to expand significantly. It was the Immigration and Naturalization Act of 1965 that set the stage for equal numbers of immigrants to come from Asia and from Europe. The Taiwanese were no exception as the first wave, and it became common for them to go to the U.S. for higher degrees and to seek new opportunities in America.

Since 1980, the number of legal immigrants from Taiwan admitted to the U.S. has grown steadily, though at a decreasing rate. By 2010, there were approximately 380,000 immigrants from Taiwan residing in the U.S., making them comparable in size to the Italian, Iranian, and Brazilian foreign-born populations. Despite accounting for only a small share of all immigrants, the Taiwanese government has estimated that more than half of all Taiwanese emigrants live in the U.S. (Taiwan Overseas Compatriot Affairs Commission, 2011). During the 1970s and 1980s, an estimated 20 percent of Taiwanese college graduates went abroad for advanced study, and few of them returned (Chen, 1995). Peaking in 1979, only 8 percent of students who studied abroad returned to Taiwan upon completing their studies (Luo and Wang, 2001), a fact that resulted in the U.S. being the largest recipient country of Taiwanese emigrants over the past three decades.

A large study conducted by economists accumulated the labor market outcomes of immigrants. ${ }^{1}$ In the U.S., Borjas $(1994,1999)$ provides detailed analyses using 1960 to 1990 censuses and current population surveys, suggesting that economic outcomes of immigrants relative to natives in the U.S. have generally deteriorated since the $1960 \mathrm{~s} .{ }^{2}$ However, there

\footnotetext{
${ }^{1}$ See, for example, the collection of research in Borjas (1994, 1999), Epstein and Gang (2010), Hanson (2006) and Zimmermann and Constant (2004).

${ }^{2}$ There are studies that reach conflicting conclusions. For example, Blau (1979) finds wage convergence between immigrants and natives, while Eichengreen and Gemery (1986) find little wage convergence between the two groups. Lubotsky (2007) uses longitudinal data and finds that the immigrant-native earnings gap closes 
are differences among immigrant groups. Borjas (1999) shows that workers from Europe and Canada, which made up 21 percent of the immigrant work force, earned 18 percent more than natives in 1990. Rivera-Batiz (2007) uses the 1980 U.S. Census and 2005 American Community Survey (ACS) and finds that immigrants from Latin America and the Caribbean (LAC) have substantially lower wages than other immigrants and the deterioration continues. Chen (1998) presents evidence that the performance of successive immigrant cohorts from mainland China declined while that of the immigrant cohorts from Hong Kong and Taiwan increased between 1980 and 1990. These findings are all in concert with the claim by Borjas (1999, p.9) that national origin matters.

[Figure 1 about here]

How have Taiwanese immigrants fared in the U.S. labor market? The initial evidence seems to favor them. For example, Figure 1 shows hourly wage ratios to natives of immigrants from Taiwan and some select immigrant groups from 1960 to 2010. In 1980, Taiwanese immigrants earned -0.03 percent lower wages than other immigrants, however, we learn that they surpassed other immigrant cohorts by 19 percent in 1990-a gap that continued to grow to 42.7 percent in 2000 and to 52.4 percent in $2010 .^{3}$ In contrast, relative wages of other immigrants, Mexico and LAC (excluding Mexico) have been declining. Furthermore, the unemployment rate of Taiwanese immigrants is lower than other immigrants in each survey, averaging 5 percent between 1980 and 2010 (6.2 percent for other immigrants). In short, the economic outcomes of immigrants from Taiwan have notably improved relative to other immigrants. ${ }^{4}$

by $10-15$ percent during immigrants' first 20 years in the U.S., or about half as fast as typical estimates from repeated cross sections of the decennial census.

${ }^{3}$ It should be noted that the cross-sectional bias is not an issue here because we examine how immigrants who have lived in the U.S. the same number of years fare and compare what accounts for earnings differences between Taiwanese and other immigrants relative to U.S. natives in a given year.

${ }^{4}$ Despite the evidence, there is little research regarding Taiwanese immigrants in the U.S. Most of the studies on immigrants from Taiwan are conducted by historians and sociologists. For example, Lu $(2004,2008)$ looks at the post-war Taiwanese immigrant society in Los Angeles and Queens of New York City from history's 
How robust is this phenomenon? Why have the labor market outcomes of immigrants from Taiwan improved and overtaken other immigrants? And which of these factors is most significant in explaining the successful economic assimilation of Taiwanese immigrants in the U.S.? ${ }^{5}$ This paper examines the explanations behind these changes and seeks to provide evidence on their relative importance.

Empirically, there are limitations in our study that can potentially affect the analysis. First, because the incidence of emigration is not likely to be a random process in the immigrant population, the endogeneity of the migration decision can bias the effects. Another limitation is the issue of return migration. These two problems, as stated in Borjas (1985, p.467), cannot be solved because of the lack of emigration data, implying that any analysis of these issues requires the making of unverifiable statistical and institutional assumptions. If we were willing to assume that those who fail in the U.S. return to their countries, the effects would bias upward. However, we demonstrate that this is most likely not the case for Taiwanese immigrants.

In this paper, we first assess the extent to which the pattern in Figure 1 is a robust phenomenon by measuring the contribution of Taiwanese immigrants' characteristics on their labor market performance. To do so, we begin estimating the earnings equations by using the 1980, 1990, and 2000 censuses and a 2010 survey. The most distinctive feature of the paper's research design is the four large decennial microdata with abundant information on individual's characteristics. This feature allows us to track and evaluate the labor market

perspective and Hong (2006) documents how the Taiwanese immigrants adapted to the U.S. immigration policy between 1980 and 2004. In particular, Pan (2004) and Lin (2009) study the history of Silicon Valley's Taiwanese immigrants from 1965 to 2000. Besides the U.S., Hsu (2002) and Yang, Chiang, and Liao (2005) examine past and current research on international migration in Taiwan, focusing on studies of Taiwanese immigrants to Australia. Gu (2006) studies the economic contributions of Taiwanese immigrants in Southeast Asia. Wang (2010) examines the Taiwanese immigrants in Yamaguchi County of Japan while Tao (2009), from sociology's perspective, considers how Taiwanese immigrants in China face the educational dilemma when choosing schools for their children.

${ }^{5}$ As stated in Borjas (1999, p.31), economic assimilation is the process of human capital accumulation that narrows the wage gap between immigrants and natives. 
performance of Taiwanese immigrants from 1980 - the year when Taiwan was first included as the birth place in the census - and also to be able to properly select reference groups from developed or developing countries, making our results comparable to the existing studies.

Our OLS estimates reveal substantial increase in the rate of returns to education for Taiwanese immigrants since 1990: in 1990, one more year of schooling increased both Taiwanese immigrants' and other immigrants' earnings by the same 5.4 percent. In 2000 , the number of Taiwanese immigrants rose to 11 percent and further increased to 14.4 percent in 2010; while that of other immigrants increased moderately to 6.7 percent and 7.5 percent in 2000 and 2010, respectively. The estimates also show that the discrepancy of returns to work experience (interpreted as pre-migration experience in the estimation) between Taiwanese and other immigrants increased from 0.4 percent in 1990 to 0.9 percent in 2000 , and rose to 1.9 percent in 2010. Furthermore, we find that one more hour worked per week increased Taiwanese immigrants' earnings by 0.4 percent in 1980, and the number increased to 1.2 percent in 2010. Collectively, these results suggest that education, pre-migration experience and the improved returns to hours worked per week are the major factors for explaining the earnings growth of Taiwanese immigrants in the U.S. labor market.

How is the performance compared with immigrants from other parts of the world? The evidence exhibits growing earnings gap between Taiwanese and other immigrants: the differential increased from $0.23 \log$ points in 1980 to $0.68 \log$ points in 2010 , growing at an average rate of 50 percent every 10 years. We decompose the differential for each decade, finding that 56 percent in 1990, 64 percent in 2000 and 73 percent in 2010 can be attributed to difference in endowments - our main finding in explaining the growing gap. Detailed decomposition supports the OLS results: we find that education alone accounts for more than two-thirds of the difference in each survey. Nonetheless, the contribution of education to the difference in endowments continued to fall significantly, dropping from more than 200 
percent in 1980 to 66.6 percent in 2010 . On the other hand, empirical evidence shows that the contribution of endowments from work experience and years since migrating to the U.S. improved from -78.6 percent and -41.8 percent in 1980 to 0.8 percent and 6.4 percent in 2010 , respectively. In the meantime, the contribution of the return to pre-migration experience rose from -38.8 percent to 4.1 percent. Although education contributes substantially to the earnings gap, we find that its importance has declined over time, however. Taken together, the results suggest that, rather than education, it is the differences in endowments of work experience, years since migrating to the U.S. and the returns to pre-migration experience that play pivotal roles for the growing earnings gap between Taiwanese and other immigrants.

Finally, after learning the determinants of the rising earnings gap and the key elements to the earnings growth of Taiwanese immigrants, we turn our analysis to assess their labor market performance by different arrival cohorts. Allowing both entry earnings and earnings growth rates to vary, we find that more recently arrival cohorts have earned more than the older ones since 1980, implying that the new generations from the island outperformed their senior counterparts in the U.S. labor market.

The remainder of the paper is organized as follows. We briefly provide the migration trend from Taiwan to the U.S in Section 2. Section 3 describes the details pertaining to the data, which we provide along with summary statistics and research design of the paper. We present and discuss the empirical results in Section 4. Finally, Section 5 concludes the paper.

\section{Migration Trend from Taiwan to the U.S.}

In 1980, legal immigrants from Taiwan numbered approximately 81,300 individuals. The number more than tripled by 1990 , reaching 257,000 , and then increased to 335,000 in 2000 . By 2010, there were 380,000 immigrants from Taiwan residing in the U.S., 57 percent of whom arrived before 1990. Since immigrants in the U.S. tend to settle in a limited number of states and cities and this geographic concentration seems to have increased over time, this 
fact reflects both the immigrants' propensity to enter the U.S. through a limited number of gateway cities and they-unlike natives-do not seem to move much around the country (Bartel, 1989; Borjas, 1999; Jaeger, 2007). Our evidence shows that Taiwanese immigrants are more likely to work in one of the three metropolitan areas, particularly Los Angeles-Long Beach, California. $^{6}$

Compared with other immigrants in 1980, 1990, 2000 and 2010, Taiwanese immigrants are over-represented in white-collar jobs, especially in managerial and professional specialties occupations. For example, in 2010, 55.7 percent of Taiwanese immigrants were in managerial and professional specialties occupations and approximately 30 percent were in technical, sales and administrative support positions. On the other hand, they are underrepresented in service and blue-collar jobs such as precision production, crafts maker, repairtype jobs, operators, fabricators, farming, forestry, fishing, etc.

In the immigration literature, the seminal works of Chiswick (1978) and Borjas (1985) have established that the skill composition of the immigrant population determines the social and economic outcomes of immigrants. An important fact of the trend in immigrant skills in the U.S. is that the relative educational attainment and economic performances of immigrant populations have changed since 1960. Compared to other immigrants, Taiwanese immigrants demonstrate relatively high educational attainment. In 1980, 40.1 percent of Taiwanese immigrants had more than a bachelor's degree (28 percent of mainland China; 6.7 percent of LAC; 15.2 percent of other immigrants). These percentages increased to 48.1 percent, 56.8 percent and 63.1 percent in 1990, 2000 and 2010, respectively. Particularly, those with graduate degrees increased from 26.2 percent in 1990 to 30.1 percent in 2000 and to 33.6 percent in 2010.

\footnotetext{
${ }^{6}$ From 1990 to 2010, more than 15 percent of Taiwanese immigrants work in Los Angeles-Long Beach, California. The second and third places are New York-Northeastern New Jersey (6.8 percent) and San Jose, California (6.7 percent).
} 
After arriving in the U.S., immigrants add to their human capital in various ways. For example, they may enroll in on-the-job training programs or study in schools where they learn skills and acquire information valuable in the U.S. labor market. Perhaps the most important part of the assimilation process is the acquisition of English language proficiency (Borjas, 1999). In fact, the literature has shown that immigrants who understand and speak English earn more than those who do not (McManus, Gould, and Welch, 1983; Rivera-Batiz, 1990; Chiswick and Miller, 1992, 1995; Rivera-Batiz, 2007). ${ }^{7}$ Table 1 shows the average English language proficiency for Taiwanese immigrants and select immigrant group from 1980 to 2010. In contrast to immigrants from LAC, the English language proficiency of Taiwanese immigrants continued to improve since 1980.

\section{Data and Research Design}

The data collection and research design were motivated by the desire to estimate the average effect of Taiwanese immigrants' characteristics on their labor market performance and to attempt to explain the rising earnings gap. We primarily use four large cross-sectional data, drawing from the 1980, 1990, and 2000 Public Use Microdata Samples of the U. S. Census and the 2010 ACS from IPUMS-USA in the Minnesota Population Center. In 1980, 1990 and 2000 the data are extracted from a 5 percent random sample of the population. The analysis is restricted to men aged 18 to 64 . A person is classified as an immigrant if he was born abroad and is either a noncitizen or a naturalized citizen; all other persons are classified as natives. People born in American Samoa, Guam, Puerto Rico, U.S. Virgin Islands, unknown or at sea are excluded from the analysis. Sampling weights are used in all calculations. To ensure the analyses are comparable, observations of Taiwanese immigrants are excluded from other immigrants.

The empirical framework follows the standard human capital literature by Mincer (1974),

\footnotetext{
${ }^{7}$ For example, after adjusting for differences in education and other socioeconomic characteristics, McManus (1985) finds that Hispanic immigrants who speak English earn 17 percent more than those who do not.
} 
Chiswick (1978) and Borjas (1985) in that the natural logarithm of the earnings of a worker $i$ is given by

$$
\ln E_{i}=\beta^{\prime} X_{i}+U_{i}
$$

where dependent variable $\ln E_{i}$ is the natural logarithm of earnings of worker $i, \beta$ is a vector of coefficients to be estimated, $X_{i}$ is a vector of individual human capital and demographic characteristics affecting earnings of worker $i$, and $U_{i}$ is a stochastic disturbance term.

Human capital and demographic variables included in the vector $X_{i}$ are as follows. First, education and work experience and its square term are used as proxies for human capital. Education is expected to have a positive effect on earnings, while the effect of work experience is assumed to initially rise and then fall. The years of work experience capture the skills of workers through seniority and aging in the labor market. Second, English language proficiency has been found to be a key human capital variable influencing the earnings of immigrants. Employment opportunities may be severely limited if the immigrant's knowledge of the English language is not sufficient (Borjas, 1999). English language proficiency on labor market outcomes generally has a positive impact on earnings (RiveraBatiz, 1990; Chiswick and Miller, 1999; Rivera-Batiz, 2007). Third, with respect to usual hours worked, it can be expected that, holding other things constant, increased hours of work per week will be associated with higher earnings (Rivera-Batiz, 2007). Fourth, married with spouse present is the marital status variable. Chiswick (1978) finds that married men tend to have higher labor force participation rates, invest more in human capital, and have better health than men who are not married. For the same age, schooling, and place of residence, married men have higher earnings. Fifth, work in metropolitan areas usually earns more than work in rural areas. Sixth, years since migrating to the U.S. and its square term. Chiswick (1978, 1999), Duleep and Regets (1999) and Rivera-Batiz (2007) have suggested that with 
limited knowledge about labor market institutions in the U.S., recent migrants may accept jobs with wage offers lower than those they would otherwise accept given their skills. As their stay increases and they are able to search for better-paying jobs, earnings will increase and they will be paid wages that correspond more closely to their skill endowments. We provide a detailed description of the variable definitions and imputations in the appendix.

[Table 1 about here]

Table 1 reports the summary statistics of the variables. It shows that the average annual earnings of Taiwanese immigrants are higher than other immigrants in each year and that the differentials become larger over time. Education, calculated by completed years of schooling, is the key explanatory variable. The four surveys consistently show that Taiwanese immigrants, on average, have more than 16 years of schooling, which exceeds those of other immigrants by 4 years. With respect to work experience, except that the five groups are similar in 2010, Taiwanese immigrants had the fewest years of work experience. Regarding English language skills, they demonstrate greater proficiency than other immigrants since 2000. As to marital status and place of work, Taiwanese immigrants are more likely to be married and to work in metropolitan areas than LAC, other immigrants and natives. Taiwanese immigrants also have more years since migrating to the U.S. starting in 2000. In summary, the evidence suggests that Taiwanese immigrants have relatively higher earnings and possess more endowments than other immigrants, particularly in education.

\section{Empirical Results}

\subsection{The OLS estimates}

Table 2 reports the results of the OLS regression using Eq.(1). In addition to Taiwanese immigrants, we report the results of three select immigrant groups which are other immigrants, immigrants from mainland China and LAC. For the convenience of comparing the effects of explanatory variables on earnings across immigrant groups and across time, we 
group the OLS estimated coefficients from the earnings equations for all immigrant groups by year. The signs of the regression coefficients on the explanatory variables are generally identical and are consistent with the theoretical expectations. Nevertheless, there are some significant differences in the magnitude of the coefficients.

[Table 2 about here]

Since 1990, the estimated returns to education for Taiwanese immigrants have been evidently increasing and surpassing other immigrants since 2000. In 1990, holding other variables constant, one more year of schooling increased Taiwanese immigrants' earnings by 5.4 percent (5.4 percent for other immigrants; 4.6 percent for mainland China; 4.1 percent for LAC). In 2000, the number increased to 11 percent (6.7 percent for other immigrants; 7.4 percent for mainland China; 4.3 percent for LAC) and to 14.4 percent (7.5 percent for other immigrants; 8.8 percent for mainland China; 4.4 percent for LAC) in 2010. A wide array of factors can be connected to the improvement in the returns to education such as quality of schooling (Rivera-Batiz, 2007). Although there is no universally agreed standard for comparing the quality of pre-migration education, changes in obtaining U.S.-earned degrees after arrival can be used as an alternative. Obtaining U.S.-earned degrees means immigrants can acquire skills and information valuable in the U.S. labor market, which then helps them assimilate in the American society. The evidence of fast-growing U.S.-earned degrees by Taiwanese immigrants supports this viewpoint. According to our calculation, the total proportion of U.S.-earned degrees of Taiwanese immigrants was 7.5 percent in 1990, while that of other immigrants from LAC (excl. Mexico) and Mexico ranged from 15.4 percent to 21.1 percent. However, in 2000 , the gap narrowed both because the percentages of U.S.earned degrees of Taiwanese immigrants continued to increase and those of the other groups decreased. From 2000 to 2010 , all immigrant groups rose steadily while Taiwan jumped from 11.5 percent to 22.3 percent. 
Another explanation for the returns to education is that they reflect a higher level of schooling for Taiwanese immigrants. As discussed in Section 2, Taiwanese immigrants have an overwhelmingly high proportion of bachelor's, master's, professional and doctorate degrees compared to other immigrants. Because higher levels of education result in better earnings, the discrepancy results in higher observed returns to education (Borjas, 1999; Rivera-Batiz, 2007).

Starting in 1990, the returns to work experience for Taiwanese immigrants are higher than those for the three reference groups. Note that we have the years of residence in the U.S. in the estimation equation, thus, the interpretation of the coefficient should be holding the number of years that an immigrant has resided in the U.S. constant and the changes in work experience variable are directly related to changes in the number of years of experience the immigrant has lived abroad (Rivera-Batiz, 2007; Chiswick and Miller, 2009). Therefore, the results indicate that the returns in the U.S. labor market of an increase in years of experience abroad brings proportionally greater returns for Taiwanese than for other immigrants. This may be the reason that Taiwanese immigrants are relatively successful in matching their occupational experience abroad with that in the U.S.

The effects of marital status and work place on earnings for Taiwanese immigrants are less than they are for other immigrants in 2000 and 1990, respectively. In particular, the coefficients of work place for Taiwanese immigrants are not significant after 2000 . Compared to other immigrants' attenuating effects of both variables on earnings, the results imply that marital status and work place become less important in determining the earnings of Taiwanese immigrants.

Although immigrants from Taiwan, on average, are more proficient in English language skills than other immigrants, empirical results in Table 2 show that English language proficiency has a quite different effect on the earnings of the two groups. First, the four 
coefficients of English Well of Taiwanese immigrants are smaller (in absolute value) than those of other immigrants. Second, unlike other immigrant groups, the coefficients of English Not At All variables are not statistically significant in 1990 and 2000. This result implies that English language skills are relatively less important in determining the earnings for Taiwanese immigrants who speak English well. Nevertheless, having poor English language skills (English Not Well or English Not At All) does have negative effects on the earnings of Taiwanese immigrants. For example, in 2000 to 2010, the estimated effects of not speaking English well are, respectively, 24.4 percent to 35.4 percent lower earnings compared to English Very Well or English only speakers.

Finally, the coefficients of Year since Migrating to the U.S. variable are higher for Taiwanese than other immigrants in each year but at a decreasing rate. Although the number of Taiwanese immigrants increased in 2010 , the estimate is barely significant at 10 percent level and its effect on earnings is smaller than that in 1980 and 1990. The result shows that the years of residence in the U.S. became less important for explaining the earnings growth of Taiwanese immigrants.

In summary, the empirical results suggests that education, pre-migration experience and improved returns to usual hours worked per week are the major factors for explaining the earnings growth of Taiwanese immigrants in the U.S. labor market. ${ }^{8}$ After accounting for sample selection issues, we investigate why this occurs and provide explanations for the change. ${ }^{9}$

\footnotetext{
${ }^{8}$ Although we show the occupations of Taiwanese immigrants in Section 2, occupations do not enter our regression analysis, as suggested in Chiswick and Miller (2009). Instead, we use mean occupational earnings as the dependent variable to account for the differing occupations among Taiwanese and other immigrants. Although we do not report the OLS and ordered probit results, it does not affect the main conclusions of the paper. Earnings and occupational attainment results are available upon request.

${ }^{9}$ We use the two-step procedure based on the work of Heckman (1976) to check for two sample selection issues: decision to work and self-employment. The insignificance of all inverse Mill's ratio coefficients indicate that our regressions do not suffer from the sample selection problem. In addition, unreported results of regression on females (as well as decomposition, cohort analysis and aging effects) show similar outcomes as males. In short, our sample selection rules should yield consistent results and will not lead to different conclusions.
} 


\subsection{Explaining the growing gap}

To explain the growing earnings gap, we first separately estimate the earnings for the two demographic groups by Eq.(1) and write it as

$$
\ln Y_{i}^{g}=\beta_{0}^{g}+\sum_{j=1}^{n} \beta_{j}^{g} X_{j i}^{g}+U_{i}^{g},
$$

where $X_{1 i} \ldots \ldots X_{n i}$ are $n$ observable characteristics, $g=a$ denotes other immigrant groups and $g=b$ denotes Taiwanese immigrants. Using the technique developed by Oaxaca (1973) and Blinder (1973), we then compute the portion of the differentials explained by the regression and rewrite the equation as

$$
\sum_{j=1}^{n} \beta_{i}^{b} \bar{X}_{j i}^{b}-\sum_{j=1}^{n} \beta_{i}^{a} \bar{X}_{j i}^{a}=\sum_{j=1}^{n} \beta_{j}^{b}\left(\bar{X}_{j}^{b}-\bar{X}_{j}^{a}\right)+\sum_{j=1}^{n} \bar{X}_{j}^{a}\left(\beta_{j}^{b}-\beta_{j}^{a}\right),
$$

where the first sum on the right hand side is "explained by endowments," while the second is “explained by coefficients".

\section{[Table 3 about here]}

Table 3 reports the decomposition results. We decompose the differential between Taiwanese immigrants and the three select immigrant groups for 1980, 1990, 2000 and 2010. For example, the log earnings of Taiwanese and other immigrants in 1980 are 5.998 and 5.770, respectively. The 0.229 earnings differential can be decomposed into 0.146 - the proportion explained by endowments and 0.083 - the proportion explained by coefficients. As the gap grows, we learned that 56 percent in 1990, 64 percent in 2000 and 73 percent and 2010 can be attributed to difference in endowments. Examining the results in Panel A of Table 3, we find that the earnings differentials between Taiwanese immigrants and the three reference groups kept growing since 1980 (except for mainland China in 2010). Not only had the coefficient of the proportion explained by endowments continued to increase, but its contribution to the differential had risen since 1990 - our main finding in explaining the 
growing gap.

Panel B of Table 3 presents the detailed decomposition results. ${ }^{10}$ We find that education contributes substantially to the difference in endowments for all groups and all years, nevertheless, its contribution continued to fall significantly. On the other hand, the contribution of endowments from work experience and years since migrating to the U.S. increased notably between 1980 and 2010. Take LAC immigrants for example, we find that the coefficient of work experience and years since migrating to the U.S. improved from 0.303 and -0.109 in 1980 to 0.004 and 0.075 in 2010 with the contributions rose from -31.5 percent and -14.8 percent to 1.8 percent and 11.3 percent-meaning that the endowments from work experience and years since migrating to the U.S. became more important for explaining the growing earnings gap between Taiwanese and LAC immigrants. Meanwhile, the contribution of the returns to work experience to the difference in coefficients increased from -38.8 percent to 4.1 percent. Considered together, these results suggest that, rather than education, the difference in endowments of work experience, years since migrating to the U.S. and the returns to work experience play essential roles in explaining the growing earnings gap between Taiwanese and other immigrants.

\subsection{Cohort analysis and aging effects}

Our analysis thus far has shown the strong economic assimilation of Taiwanese immigrants in the U.S. labor market. These results are based on cross-section regressions between 1980 and 2010. Borjas (1985) stresses that cross-section studies of immigrant earnings growth confound the true assimilation impact with across-cohort changes in the economic performance of immigrants. As a result, the cross-section analysis does not

\footnotetext{
${ }^{10}$ A related issue that has received attention in the literature is that detailed decomposition is not invariant to the choice of the reference category when sets of dummy variables are used (Oaxaca and Ransom, 1999; Horrace and Oaxaca, 2001; Gardeazabal and Ugidos, 2004; Yun, 2005; Jann, 2008). If a model includes dummy variables, then the sum of the detailed coefficient effects attributed to the dummy variables is not invariant to the choice of the reference or the omitted category (Powers, Yoshioka, and Yun, 2011). As we have several categorical variables in our regressions, we apply the solution proposed by Gardeazabal and Ugidos (2004) and Yun (2005) and implement the method in Jann (2008).
} 
account for the effects of aging on the impact of assimilation. Furthermore, we find a systematic and inverse relationship between entry earnings and earnings growth in each immigrant group. Therefore, a methodology must be pursued which can estimate each cohort's earnings growth separately rather than pooling and assuming a fixed earnings growth rate across cohorts. To respond this issue, we present a method that allows both entry earnings and earnings growth rates to vary. ${ }^{11}$

Consider cohort $h$. The year $t$ regression predicts that over 10 years the "cross-section" growth for cohort $h$ is given by

$$
\underbrace{\hat{Y}_{t, h}-\hat{Y}_{t, h+10}}_{\text {Cross-section growth }}=\underbrace{\left(\hat{Y}_{t, h}-\hat{Y}_{t-10, h}\right)}_{\text {Within-cohort growth }}+\underbrace{\left(\hat{Y}_{t-10, h}-\hat{Y}_{t, h+10}\right)}_{\text {Across-cohort growth }},
$$

where $\hat{Y}$ is the estimated value of the log earnings. The first term on the right hand side of Eq.(2) gives the earnings growth experienced by cohort $h$ over the 10 years and is called the "within-cohort" growth. The second term on the right hand side estimates the difference in earnings that occurred over the 10 years for individuals with a given number of years since immigration. It compares different cohorts at the same point of their U.S. life cycle and is called the "across-cohort" earnings growth (Borjas, 1985). Therefore, Eq.(2) illustrates that the comparison of immigrant cross sections over time can be used to infer the extent to which the underlying assimilation process of immigrant cohorts is changing.

To account for the effect of secular changes in aggregate labor market conditions, the cross-section growth in the relative earnings of immigrant cohort $h$ to native workers $n$ is

$$
\underbrace{\hat{\beta}_{h}-\hat{\beta}_{h+10}}_{\text {Cross-section growth }}=[\underbrace{\left[\left(\hat{Y}_{t, h}-\hat{Y}_{t, n}\right)-\left(\hat{Y}_{t-10, h}-\hat{Y}_{t-10, n}\right)\right]}_{\text {Within-cohort growth }}+\underbrace{\left[\left(\hat{Y}_{t-10, h}-\hat{Y}_{t-10, n}\right)-\left(\hat{Y}_{t, h+10}-\hat{Y}_{t, n}\right)\right]}_{\text {Across-cohort growth }} .
$$

The first bracketed term in Eq.(3) gives the difference in the relative earnings of cohort $h$ between year $t$ and $t-10$. This within-cohort growth measures the rate at which the earnings

\footnotetext{
${ }^{11}$ The method is motivated by Duleep and Regets (2002) in that they address the problem inherent in the pooled cross-sectional methodology pioneered by Borjas (1985).
} 
profiles of immigrants and natives are converging/diverging (Borjas, 1985). The second bracketed term in Eq.(3) gives the across-cohort effect.

[Table 4 about here]

Table 4 reports the cohort analysis results from Eq.(2) and Eq.(3). The "across-cohort" growth compares the 10 year labor market performance between an old cohort $(h)$ and a recent cohort $(h+10)$. A negative sign of "across-cohort" growth means that giving both cohorts 10 years to work in the U.S., the earnings growth of the old cohort is less than those of the recent cohort. In other words, the economic performance of the recent cohort is better if the sign of the "across-cohort" growth is negative. Take Taiwanese immigrants for example, Table 4 shows that all three cases of cohort differences in the absolute earnings and two cases in the relative earnings reveal negative signs. ${ }^{12}$ Although the first case of the relative earnings did not reach statistical significance, a certain trend was noted, suggesting that more recently arrival cohorts of Taiwanese immigrants had earned more than the older ones since $1980 .^{13}$

In any cross-section, the effect of aging must be taken into account when studying the determinants of earnings. If the coefficients of work experience are roughly similar, the effect of aging on the relative earnings of immigrants would not be very important. Our regression results in Table 2 do not support such case; therefore, it is imperative to measure

\footnotetext{
${ }^{12}$ In the relative earnings cohort analysis, the choice of reference group can be complex. Borjas (1985) compares immigrants' earnings to their native counterparts and finds little difference. In addition to using all natives as the reference group, we also use Taiwanese American (only available in 1990 and 2000) as the native counterparts for Taiwanese immigrants. The results also show a relatively better performance for recent Taiwanese immigrants.

${ }^{13}$ Some concerns have been raised about the method used in Borjas (1985), however. For example, using matched CPS and 1970 to 1990 censuses, Duleep and Regets $(1997,2002)$ find different results such that immigrant year-to-year earnings growth rates are greater than those for natives in true panel data, and they present strong evidence of a systematic and inverse relationship (correlation -.489 for 1980 to 1990) between entry earnings of immigrants and subsequent earnings growth. Following Duleep and Regets (2002), we group age and education into two categories and find the correlation between the relative entry earnings (with respect to natives) of Taiwanese immigrants and their real earnings growth rates for the cohort aged 40 to 64 with education of 1 to 12 years is -.332 and -.388 while for cohort aged 40 to 64 with education of 13 years or more (-.960 for cohort of age 18 to 39 with education 1 to 12 years). Because of the minimal number of observations, estimations cannot proceed. Nevertheless, instead we use a group of Asian immigrants and find that a 0.1 unit decrease of relative entry earnings would raise their real earnings growth rate by 4.13 percent and 3.04 percent for 2000 to 2010 and 1990 to 2000, respectively — suggesting a statistically significant relationship.
} 
the degree to which the aging effect impacts our findings. Following Borjas (1985)Luo and Wang, 2001, the change in the relative earnings of immigrants compared to natives due purely to the aging effect can be shown as

$$
A_{i}-A_{n}=10\left(\hat{\beta}_{E X P, i}-\hat{\beta}_{E X P, n}\right)+\left(\hat{\beta}_{E X P^{2}, i}-\hat{\beta}_{E X P^{2}, n}\right)(20 E X P-100)
$$

The bottom panel of Table 4 reports the aging effect using Eq.(4). For Taiwanese immigrant men in the 1990 to 1999 cohort, a 10 year increase in age raises the relative earnings by 3.6 percent. On the other hand, for Taiwanese immigrant men from the 1980 to 1989 and 1970 to 1979 cohorts, a 10 year increase in age lowers the relative earnings by 21.4 percent and 33.3 percent, respectively. ${ }^{14}$ When these quantities are added to the withincohort growth presented in Table 4, the relative earnings and assimilation rates of Taiwanese immigrants increase for the recent cohort but decrease for the older cohorts due to the aging effect. In spite of the fact that pure aging effects do not work in favor of the older Taiwanese immigrant cohorts, it does not alter the outcome of relatively better performances by Taiwanese immigrants.

\section{Conclusions}

Despite accounting for only a small share of all immigrants, more than half of Taiwan's emigrants live in the U.S., making the U.S. the largest recipient country of Taiwanese emigrants over the past three decades. This paper presents evidence that, relative to other immigrants, the earnings of Taiwanese immigrants have grown rapidly as they assimilate into the U.S. economy, and it attempts to provide explanations for their performance.

We began with estimating the earnings equations of Taiwanese immigrants and sought to explain their earnings growth for the past 30 years. The estimates have shown that the rising returns to education and pre-migration experience for Taiwanese immigrants, along with

\footnotetext{
${ }^{14}$ These numbers are larger than those reported in Borjas (1985) which are $12 \%$ to $15 \%$ for Asian immigrants, meaning that the pure aging effect has a greater impact on older Taiwanese immigrant cohorts than it does on other Asian immigrants.
} 
improved returns to hours worked per week, could account for their relatively successful economic assimilation. To seek explanations for the growing earnings gap between Taiwanese and other immigrants, we investigated the earnings differential by decomposition technique. The results suggest that the growing gaps are largely explained by differences in individuals' endowments - of which more than two-thirds can be solely attributed to education in each year, however, its importance continued to fall significantly. Instead, we demonstrated that the differences in endowments from work experience, years since migrating to the U.S. and the returns to pre-migration experience play important roles for explaining the growing gap. Finally, we assessed the performances of Taiwanese immigrants by different arrival cohorts. Our exercise shows that more recently arrival cohorts have earned more than the older ones since 1980, implying that the new generations from the island outperformed their senior counterparts in the U.S. labor market.

\section{Appendix: Variable Definition}

\section{Definition of Annual Earnings}

These variables are calculated in the sample of men who do not reside in group quarters; are employed in the civilian labor force; are not enrolled in school; report positive annual earnings, weeks worked, and weekly hour; and are not self-employed. The annual earnings in 1980, 1990 and 2000 are then adjusted for inflation and converted to 2010 constant dollars.

\section{Definition of Weeks Worked Last Year}

In the 2010 ACS, weeks worked in the calendar year prior to the survey are reported as a categorical variable. We impute weeks worked for each worker as follows: 7 for 13 weeks or less, 20 for 14 to 26 weeks, 33 for 27 to 39 weeks, 43.5 for 40 to 47 weeks, 48.5 for 48 to 49 weeks, and 51 for 50 to 52 weeks.

\section{Definition of Education and Work Experience}

Because of differences in the coding of the completed education variable across surveys, 
to compute completed years of education, using the 1990 census, we assign 2.5 for grades 1 , 2, 3, or $4 ; 6.5$ for grades $5,6,7$, or $8 ; 12$ for grade 12 and high school graduate or GED (General Educational Development certificate). Using the 2000 census, we assign 2.5 for nursery school to grade $4 ; 5.5$ for grade 5 or $6 ; 7.5$ for grade 7 or $8 ; 12.5$ for some college but less than 1 year. These imputations are consistent with the method used in Rouse (1995).

In all surveys (except 1980), we assign 1 or more years of college credit but no degree 13 years, an associate's degree 14 years, and a bachelor's degree 16 years. Those who have a master's degree are given 18 years, a professional degree beyond a bachelor's degree is given 19 years, and a doctoral degree corresponds to 20 years of education. We define work experience as the worker's age at the time of the survey minus years of completed education minus 6 . We restrict the analysis to persons who have between 1 and 45 years of experience. Definition of Years since Migrating to the U.S.

In the 1980 and 1990 censuses, the respondent was asked to report the range of years that included their year of arrival such as 1990 for 1987 to 1990 . We impute years since migration for each worker as follows: 1988.5 for 1987 to $1990,1985.5$ for 1985 to 1986 , 1983 for 1982 to $1984,1980.5$ for 1980 to 1981,1977 for 1975 to 1979 (1990 census), 1977.5 for 1975 to 1980 (1980 census), 1972 for 1970 to 1974,1967 for 1965 to 1969,1962 for 1960 to 1964 , and 1954.5 for 1950 to 1959.

\section{References}

Bartel, A.P., (1989). Where Do the New U.S. Immigrants Live? Journal of Labor Economics 7, 371-391.

Blau, F.D., (1979). Immigration and Labor Earnings in Early Twentieth Century America, in: Simon J.L., DaVanzo J. (Eds), Research in Population Economics, vol. 2. JAI Press, Greenwich, CT; pp. 21-41.

Blinder, A.S., (1973). Wage Discrimination: Reduced Form and Structural Estimates. The Journal of Human Resources 8, 436-455.

Borjas, G.J., (1985). Assimilation, Changes in Cohort Quality, and the Earnings of Immigrants. Journal of Labor Economics 3, 463-489. 
Borjas, G.J., (1994). The Economics of Immigration. Journal of Economic Literature 32, 1667-1717.

Borjas, G.J., (1999) Heaven's Door : Immigration Policy and the American Economy. Princeton University Press: Princeton, N.J.

Chen, S.-J., (1995). Economic Progress and International Mobility of Human Resources: Chinese Immigrants in the United States Labor Market, vol. Ph.D. University of Illinois at Urbana-Champaign, Ph.D. Thesis.

Chen, S.-J., (1998). Characteristics and Assimilation of Chinese Immigrants in the Us Labour Market. Int Migr 36, 187-210.

Chiswick, B.R., (1978). The Effect of Americanization on the Earnings of Foreign-Born Men. Journal of Political Economy 86, 897-921.

Chiswick, B.R., (1999). Are Immigrants Favorably Self-Selected? American Economic Review 89, 181-185.

Chiswick, B.R., Miller P.W., (1992). Language in the Immigrant Labor Market, in: Chiswick B.R. (Ed), Immigration, Language and Ethnicity, Canada and the United States. American Enterprise Institute, Washington, D.C.; pp. 229-296.

Chiswick, B.R., Miller P.W., (1995). The Endogeneity between Language and Earnings: International Analyses. Journal of Labor Economics 13, 246-288.

Chiswick, B.R., Miller P.W., (1999). Language Skills and Earnings among Legalized Aliens. Journal of Population Economics 12, 63-89.

Chiswick, B.R., Miller P.W., (2009). Earnings and Occupational Attainment among Immigrants. Industrial Relations: A Journal of Economy and Society 48, 454-465.

Duleep, H.O., Regets M.C., (1997). Measuring Immigrant Wage Growth Using Matched Cps Files. Demography 34, 239-249.

Duleep, H.O., Regets M.C., (1999). Immigrants and Human-Capital Investment. American Economic Review 89, 186-191.

Duleep, H.O., Regets M.C., (2002). The Elusive Concept of Immigrant Quality: Evidence from 1970-1990, IZA Discussion Paper No. 631. Institute for the Study of Labor (IZA).

Eichengreen, B., Gemery H.A., (1986). The Earnings of Skilled and Unskilled Immigrants at the End of the Nineteenth Century. Journal of Economic History 46, 441-454.

Epstein, G.S., Gang I.N., (2010) Migration and Culture. Emerald Group Publishing Limited.

Gardeazabal, J., Ugidos A., (2004). More on Identification in Detailed Wage Decompositions. The Review of Economics and Statistics 86, 1034-1036.

Gu, C.-Y., (2006). Taiwanese Immigrants in Southeast Asia and Economic Relationship. Journal of Taiwan and Southeast Asia 3, 105-125.

Hanson, G.H., (2006). Illegal Migration from Mexico to the United States. Journal of Economic Literature 44, 869-924.

Heckman, J.J., (1976). The Common Structure of Statistical Models of Truncation, Sample Selection and Limited Dependent Variables and a Simple Estimator for Such Models. Annals of Econometrics and Social Measurement 5, 120-137.

Hong, Y.-R., (2006). Taiwanese Immigrants under the Current U.S. Immigration Policy, 1980-2004. Chung Hsing History 12, 153-196. 
Horrace, W.C., Oaxaca R.L., (2001). Inter-Industry Wage Differentials and the Gender Wage Gap: An Identification Problem. Industrial and Labor Relations Review 54, 611-618.

Hsu, J.-C., (2002). Evolution of Australian Immigration Policy and Taiwanese Immigrants. Journal of Taipei Municipal University of Education 33, 379-388.

Jaeger, D.A., (2007). Green Cards and the Location Choices of Immigrants in the United States, 1971-2000. Research in Labor Economics 27, 131-184.

Jann, B., (2008). A Stata Implementation of the Blinder-Oaxaca Decomposition. Chair of Sociology, ETH Zurich.

Lin, H.-M., (2009). The Research of Taiwanese High-Tech Immigrants in the Silicon Valley, Master's Thesis. National Chung Hsing University.

Lu, P.-F., (2004). The Post-War Taiwanese Immigrant Society in Queens of New York, 1945-2000, Master's Thesis, vol. Master's. National Chung Hsing University.

Lu, P.-F., (2008). Chinese Media and Taiwanese Immigrant Society in Los Angeles. Chung Hsing History 14, 63-80.

Lubotsky, D., (2007). Chutes or Ladders? A Longitudinal Analysis of Immigrant Earnings. Journal of Political Economy 115, 820-867.

Luo, Y.-L., Wang W.-J., (2001). High-Skilled Migration and Chinese Taipei's Industrial Development, International Mobility of the High Skilled. OECD, Paris; pp. 253-269.

McManus, W., Gould W., Welch F., (1983). Earnings of Hispanic Men: The Role of English Language Proficiency. Journal of Labor Economics 1, 101-130.

McManus, W.S., (1985). Labor Market Costs of Language Disparity: An Interpretation of Hispanic Earnings Differences. American Economic Review 75, 818-827.

Mincer, J., (1974) Schooling, Experience, and Earnings. NBER and Columbia University Press.

Oaxaca, R.L., (1973). Male-Female Wage Differentials in Urban Labor Markets. International Economic Review 14, 693-709.

Oaxaca, R.L., Ransom M.R., (1999). Identification in Detailed Wage Decompositions. The Review of Economics and Statistics 81, 154-157.

Pan, H.-Y., (2004). Silicon Valley's Taiwanese Immigrants, 1965-2000, Master's Thesis. National Chung Hsing University.

Powers, D.A., Yoshioka H., Yun M.-S., (2011). Mvdcmp: Multivariate Decomposition for Nonlinear Response Models. Stata Journal 11, 556-576.

Rivera-Batiz, F.L., (1990). English Language Proficiency and the Economic Progress of Immigrants. Economics Letters 34, 295-300.

Rivera-Batiz, F.L., (2007). How Do Migrants from Latin America and the Caribbean Fare in the Us Labour Market? World Econ 30, 1399-1429.

Taiwan Overseas Compatriot Affairs Commission. (2011). Longitudinal Survey of Migrants to the U.S. From Taiwan. Taipei.

Tao, M.-C., (2009). Child Education and School Choice: Taiwanese Immigrants in China, Master's Thesis, vol. Master's. National Tsing Hua University.

Wang, R.-H., (2010). The Formation and Development of Overseas Chinese Society in Japan-a Case Study on Taiwanese Immigrants in Yamaguchi, Master's Thesis. National Chung Hsing University. 
Yang, C.-H., Chiang L.-H.N., Liao P.-C., (2005). Current Research on Taiwanese Immigration to Australia. Environment and the World 11, 33-64.

Yun, M.-S., (2005). A Simple Solution to the Identification Problem in Detailed Wage Decompositions. Economic Inquiry 43, 766-772.

Zimmermann, K.F., Constant A., (2004) How Labor Migrants Fare. Springer: Berlin ; New York. 
Table 1. Summary Statistics

\begin{tabular}{|c|c|c|c|c|c|c|c|c|c|c|c|}
\hline \multirow{2}{*}{ Variables } & \multirow{2}{*}{ Year } & \multicolumn{2}{|c|}{ Taiwan } & \multicolumn{2}{|c|}{$\begin{array}{c}\text { Other } \\
\text { Immigrants }\end{array}$} & \multicolumn{2}{|c|}{ Natives } & \multicolumn{2}{|c|}{$\begin{array}{c}\text { Mainland } \\
\text { China }\end{array}$} & \multicolumn{2}{|c|}{ LAC } \\
\hline & & Mean & S.D. & Mean & S.D. & Mean & S.D. & Mean & S.D. & Mean & S.D. \\
\hline \multirow{4}{*}{$\begin{array}{r}\text { Earnings } \\
\text { (dollar) }\end{array}$} & 2010 & 84,152 & 68,370 & 45,972 & 53,406 & 56,625 & 56,002 & 60,354 & 58,970 & 30,948 & 30,641 \\
\hline & 2000 & 83,767 & 71,817 & 47,546 & 55,680 & 57,385 & 57,054 & 54,867 & 54,761 & 32,602 & 35,139 \\
\hline & 1990 & 64,975 & 49,129 & 44,442 & 42,594 & 51,359 & 41,503 & 47,788 & 44,726 & 31,114 & 27,497 \\
\hline & 1980 & 51,775 & 34,392 & 42,476 & 31,395 & 46,209 & 29,222 & 42,364 & 31,343 & 31,324 & 22,452 \\
\hline \multirow{4}{*}{ Education } & 2010 & 16.57 & 2.54 & 12.15 & 4.27 & 13.74 & 2.44 & 14.78 & 4.57 & 10.33 & 3.92 \\
\hline & 2000 & 16.68 & 2.84 & 11.94 & 4.56 & 13.52 & 2.44 & 14.52 & 4.77 & 9.81 & 4.34 \\
\hline & 1990 & 16.27 & 4.12 & 11.35 & 5.02 & 12.89 & 3.33 & 12.89 & 5.13 & 9.19 & 4.76 \\
\hline & 1980 & 17.07 & 3.43 & 11.58 & 4.72 & 12.76 & 2.94 & 13.24 & 5.19 & 9.33 & 4.55 \\
\hline \multirow{4}{*}{$\begin{array}{r}\text { Work } \\
\text { Experience }\end{array}$} & 2010 & 21.45 & 10.27 & 21.44 & 10.90 & 21.82 & 11.80 & 21.65 & 11.12 & 21.35 & 10.86 \\
\hline & 2000 & 17.93 & 9.38 & 19.50 & 10.63 & 20.34 & 10.95 & 21.00 & 11.20 & 19.23 & 10.55 \\
\hline & 1990 & 15.59 & 8.64 & 19.53 & 10.94 & 19.04 & 11.22 & 24.36 & 10.34 & 19.15 & 10.76 \\
\hline & 1980 & 12.35 & 7.80 & 20.48 & 11.84 & 18.62 & 12.42 & 21.73 & 11.66 & 19.63 & 11.28 \\
\hline \multirow{4}{*}{$\begin{array}{r}\text { English } \\
\text { Language } \\
\text { Proficiency }\end{array}$} & 2010 & 2.48 & .73 & 2.26 & 1.20 & - & - & 1.96 & 1.01 & 1.77 & 1.05 \\
\hline & 2000 & 2.46 & .66 & 2.36 & 1.21 & - & - & 1.99 & .98 & 1.82 & 1.07 \\
\hline & 1990 & 2.36 & .69 & 2.47 & 1.19 & - & - & 1.88 & .99 & 1.88 & 1.04 \\
\hline & 1980 & 2.29 & .71 & 2.50 & 1.19 & - & - & 2.01 & .93 & 1.82 & 1.04 \\
\hline \multirow{4}{*}{$\begin{array}{r}\text { Usual Hours } \\
\text { Worked Per } \\
\text { Week }\end{array}$} & 2010 & 43.48 & 10.16 & 41.56 & 9.58 & 42.92 & 10.35 & 42.61 & 10.37 & 40.70 & 9.11 \\
\hline & 2000 & 44.29 & 10.47 & 43.44 & 10.15 & 44.35 & 9.89 & 43.56 & 10.86 & 42.72 & 9.64 \\
\hline & 1990 & 42.90 & 9.49 & 43.03 & 10.29 & 43.70 & 9.80 & 44.10 & 13.21 & 42.24 & 10.19 \\
\hline & 1980 & 41.70 & 10.64 & 42.01 & 9.52 & 42.68 & 9.17 & 42.94 & 9.83 & 41.20 & 9.33 \\
\hline \multirow{4}{*}{$\begin{array}{r}\text { Married with } \\
\text { Spouse } \\
\text { Present }\end{array}$} & 2010 & .71 & .45 & .57 & .50 & .57 & .49 & .71 & .47 & .49 & .50 \\
\hline & 2000 & .73 & .45 & .60 & .49 & .63 & .48 & .74 & .44 & .53 & .50 \\
\hline & 1990 & .77 & .42 & .63 & .48 & .66 & .47 & .78 & .41 & .57 & .50 \\
\hline & 1980 & .82 & .39 & .73 & .44 & .72 & .45 & .80 & .40 & .69 & .46 \\
\hline \multirow{4}{*}{$\begin{array}{r}\text { Work in } \\
\text { Metropolitan } \\
\text { Areas }\end{array}$} & 2010 & .92 & .27 & .87 & .34 & .75 & .43 & .92 & .27 & .84 & .36 \\
\hline & 2000 & .94 & .24 & .87 & .34 & .75 & .43 & .93 & .25 & .84 & .37 \\
\hline & 1990 & .93 & .25 & .90 & .30 & .72 & .45 & .94 & .24 & .91 & .29 \\
\hline & 1980 & .88 & .32 & .81 & .39 & .65 & .48 & .89 & .31 & .82 & .33 \\
\hline \multirow{4}{*}{$\begin{array}{l}\text { Years since } \\
\text { Migrating to } \\
\text { the U.S. }\end{array}$} & 2010 & 22.75 & 10.14 & 18.01 & 12.11 & - & - & 15.28 & 9.72 & 16.84 & 10.95 \\
\hline & 2000 & 17.41 & 8.26 & 15.92 & 11.51 & - & - & 13.45 & 9.75 & 14.29 & 10.13 \\
\hline & 1990 & 11.98 & 7.44 & 15.37 & 10.72 & - & - & 14.71 & 11.04 & 13.13 & 9.09 \\
\hline & 1980 & 8.71 & 5.92 & 14.34 & 9.52 & - & - & 13.69 & 9.35 & 11.71 & 8.06 \\
\hline \multirow{4}{*}{ Observations } & 2010 & \multicolumn{2}{|c|}{866} & \multicolumn{2}{|c|}{84,899} & \multicolumn{2}{|c|}{428,600} & \multicolumn{2}{|c|}{2,930} & \multicolumn{2}{|c|}{45,407} \\
\hline & 2000 & \multirow{2}{*}{\multicolumn{2}{|c|}{$\begin{array}{l}3,157 \\
2.125\end{array}$}} & \multirow{2}{*}{\multicolumn{2}{|c|}{$\begin{array}{l}327,016 \\
196,096\end{array}$}} & \multicolumn{2}{|c|}{$2,128,150$} & & & & 972 \\
\hline & 1990 & & & & & $2,01($ & 0,309 & & & & \\
\hline & 1980 & 58 & & 123 & 227 & $1,87 \varepsilon$ & 3,358 & & & & \\
\hline
\end{tabular}

Note: Samples are men between 18 and 64 years of age with positive earnings and hours of work, not selfemployed, not in the group quarters and not in school. The earnings have been adjusted for inflation and expressed in 2010 dollars. The column "Other Immigrants" in the table excludes those from Taiwan. 
Table 2. OLS Regression Results

\begin{tabular}{|c|c|c|c|c|c|}
\hline \multirow{2}{*}{$\begin{array}{l}\text { Dependent Variable: Log Earnings } \\
\text { Independent Variables }\end{array}$} & \multirow[b]{2}{*}{ Year } & \multirow[b]{2}{*}{ Taiwan } & \multicolumn{3}{|c|}{ Reference Groups } \\
\hline & & & $\begin{array}{c}\text { Other } \\
\text { Immigrants }\end{array}$ & $\begin{array}{l}\text { Mainland } \\
\text { China }\end{array}$ & LAC \\
\hline \multirow{4}{*}{ Education } & 2010 & $.144^{* *}$ & $.075^{* *}$ & $.088^{* *}$ & $.044^{* *}$ \\
\hline & 2000 & $.110^{* *}$ & $.067^{* *}$ & $.074^{* *}$ & $.043^{* *}$ \\
\hline & 1990 & $.054^{* *}$ & $.054^{* *}$ & $.046^{* *}$ & $.041^{* *}$ \\
\hline & 1980 & $.066^{* *}$ & $.055^{* *}$ & $.052^{* *}$ & $.043^{* *}$ \\
\hline \multirow{5}{*}{ Work Experience } & 2010 & $.059^{* *}$ & $.040^{* *}$ & $.036^{* *}$ & $.039^{* *}$ \\
\hline & 2000 & $.042^{* *}$ & $.033^{* *}$ & $.019^{* *}$ & $.032^{* *}$ \\
\hline & 1990 & $.048^{* *}$ & $.044^{* *}$ & $.026^{* *}$ & $.037^{* *}$ \\
\hline & 1980 & $.035^{* *}$ & $.048^{* *}$ & $.016^{* *}$ & $.042^{* *}$ \\
\hline & 2010 & $-.123^{* *}$ & $-.064^{* *}$ & $-.066^{* *}$ & $-.064^{* *}$ \\
\hline \multirow{3}{*}{ Work Experience Squared/100 } & 2000 & $-.089^{* *}$ & $-.054^{* *}$ & $-.045^{* *}$ & $-.054^{* *}$ \\
\hline & 1990 & $-.094^{* *}$ & $-.068^{* *}$ & $-.050^{* *}$ & $-.063^{* *}$ \\
\hline & 1980 & $-.079^{* *}$ & $-.079^{* *}$ & $-.029^{* *}$ & $-.072^{* *}$ \\
\hline \multirow{4}{*}{$\begin{array}{r}\text { Log Usual Hours Worked Per } \\
\text { Week }\end{array}$} & 2010 & $1.173^{* *}$ & $.980^{* *}$ & $.676^{* *}$ & $.875^{* *}$ \\
\hline & 2000 & $.750^{* *}$ & $.785^{* *}$ & $.643^{* *}$ & $.644^{* *}$ \\
\hline & 1990 & $.857^{* *}$ & $.803^{* *}$ & $.521^{* *}$ & $.690^{* *}$ \\
\hline & 1980 & $.435^{* *}$ & $.375^{* *}$ & $.283^{* *}$ & $.295^{* *}$ \\
\hline \multirow{4}{*}{ Married with Spouse Present } & 2010 & $.137^{* *}$ & $.197^{* *}$ & $.126^{* *}$ & $.144^{* *}$ \\
\hline & 2000 & $.151^{* *}$ & $.220^{* *}$ & $.178^{* *}$ & $.202^{* *}$ \\
\hline & 1990 & $.364^{* *}$ & $.237^{* *}$ & $.167^{* *}$ & $.206^{* *}$ \\
\hline & 1980 & $.239^{* *}$ & $.242^{* *}$ & $.230^{* *}$ & $.224^{* *}$ \\
\hline \multirow{4}{*}{ Work in Metropolitan Areas } & 2010 & .099 & $.113^{* *}$ & $.168^{* *}$ & $.049^{* *}$ \\
\hline & 2000 & .070 & $.122^{* *}$ & $.063^{*}$ & $.074^{* *}$ \\
\hline & 1990 & $.180^{* *}$ & $.173^{* *}$ & $.102^{* *}$ & $.203^{* *}$ \\
\hline & 1980 & $.132^{* *}$ & $.022^{* *}$ & $.047^{* *}$ & $.020^{* *}$ \\
\hline \multirow{4}{*}{ Years since Migrating to the U.S. } & 2010 & $.022^{*}$ & $.010^{* *}$ & $.020^{* *}$ & $.013^{* *}$ \\
\hline & 2000 & $.016^{* *}$ & $.013^{* *}$ & $.025^{* *}$ & $.019^{* *}$ \\
\hline & 1990 & $.040^{* *}$ & $.022^{* *}$ & $.045^{* *}$ & $.031^{* *}$ \\
\hline & 1980 & $.056^{* *}$ & $.030^{* *}$ & $.045^{* *}$ & $.036^{* *}$ \\
\hline \multirow{4}{*}{$\begin{array}{l}\text { Years since Migrating to the U.S. } \\
\text { Squared/100 }\end{array}$} & 2010 & -.032 & $-.012^{* *}$ & $-.025^{* *}$ & $-.008^{* *}$ \\
\hline & 2000 & $-.026^{*}$ & $-.013^{* *}$ & $-.028^{* *}$ & $-.017^{* *}$ \\
\hline & 1990 & $-.082^{* *}$ & $-.029^{* *}$ & $-.067^{* *}$ & $-.043^{* *}$ \\
\hline & 1980 & $-.137^{* *}$ & $-.059^{* *}$ & $-.090^{* *}$ & $-.072^{* *}$ \\
\hline \multirow{4}{*}{ English Well } & 2010 & $-.160^{* *}$ & $-.228^{* *}$ & $-.251^{* *}$ & $-.143^{* *}$ \\
\hline & 2000 & $-.058^{* *}$ & $-.176^{* *}$ & $-.209^{* *}$ & $-.095^{* *}$ \\
\hline & 1990 & $-.123^{* *}$ & $-.158^{* *}$ & $-.250^{* *}$ & $-.098^{* *}$ \\
\hline & 1980 & $-.114^{* *}$ & $-.126^{* *}$ & $-.228^{* *}$ & $-.055^{* *}$ \\
\hline \multirow{4}{*}{ English Not Well } & 2010 & $-.354^{* *}$ & $-.326^{* *}$ & $-.599^{* *}$ & $-.241^{* *}$ \\
\hline & 2000 & $-.244^{* *}$ & $-.296^{* *}$ & $-.589^{* *}$ & $-.192^{* *}$ \\
\hline & 1990 & $-.519^{* *}$ & $-.336^{* *}$ & $-.579^{* *}$ & $-.224^{* *}$ \\
\hline & 1980 & $-.299^{* *}$ & $-.267^{* *}$ & $-.486^{* *}$ & $-.169^{* *}$ \\
\hline \multirow{3}{*}{ English Not At All } & 2010 & $-.429^{* *}$ & $-.349^{* *}$ & $-.716^{* *}$ & $-.293^{* *}$ \\
\hline & 2000 & -.415 & $-.347^{* *}$ & $-.629^{* *}$ & $-.266^{* *}$ \\
\hline & 1990 & -.268 & $-.459^{* *}$ & $-.643^{* *}$ & $-.334^{* *}$ \\
\hline
\end{tabular}




\begin{tabular}{cccccc} 
& 1980 & $-.411^{*}$ & $-.358^{* *}$ & $-.654^{* *}$ & $-.264^{* *}$ \\
& 2010 & $-1.368^{* *}$ & $.518^{* *}$ & $1.595^{* *}$ & $1.166^{* *}$ \\
Constant & 2000 & $1.055^{* *}$ & $1.390^{* *}$ & $2.078^{* *}$ & $2.043^{* *}$ \\
& 1990 & $1.017^{* *}$ & $1.214^{* *}$ & $2.607^{* *}$ & $1.612^{* *}$ \\
& 1980 & $2.501^{* *}$ & $2.866^{* *}$ & $3.493^{* *}$ & $3.199^{* *}$ \\
& 2010 & 866 & 84,899 & 2,930 & 45,407 \\
Observations & 2000 & 3,157 & 327,016 & 8,710 & 178,972 \\
& 1990 & 2,125 & 196,096 & 4,663 & 96,750 \\
\multirow{5}{*}{ Adjusted $\mathrm{R}^{2}$} & 1980 & 587 & 123,227 & 3,379 & 51,201 \\
& 2010 & .462 & .413 & .485 & .319 \\
& 2000 & .325 & .360 & .427 & .277 \\
& 1990 & .374 & .381 & .412 & .318 \\
& 1980 & .346 & .292 & .375 & .215
\end{tabular}

Note: ${ }^{* *}$ and ${ }^{*}$ indicate that the estimate is statistically significant at the 5 percent and 10 percent levels, respectively. The reference category of English language proficiency is English only and English very well. In the three reference benchmarks of other immigrants, the observations of Taiwanese immigrants are excluded. 
Table 3. Earnings Gap Decomposition between Taiwanese and Select Immigrant Groups

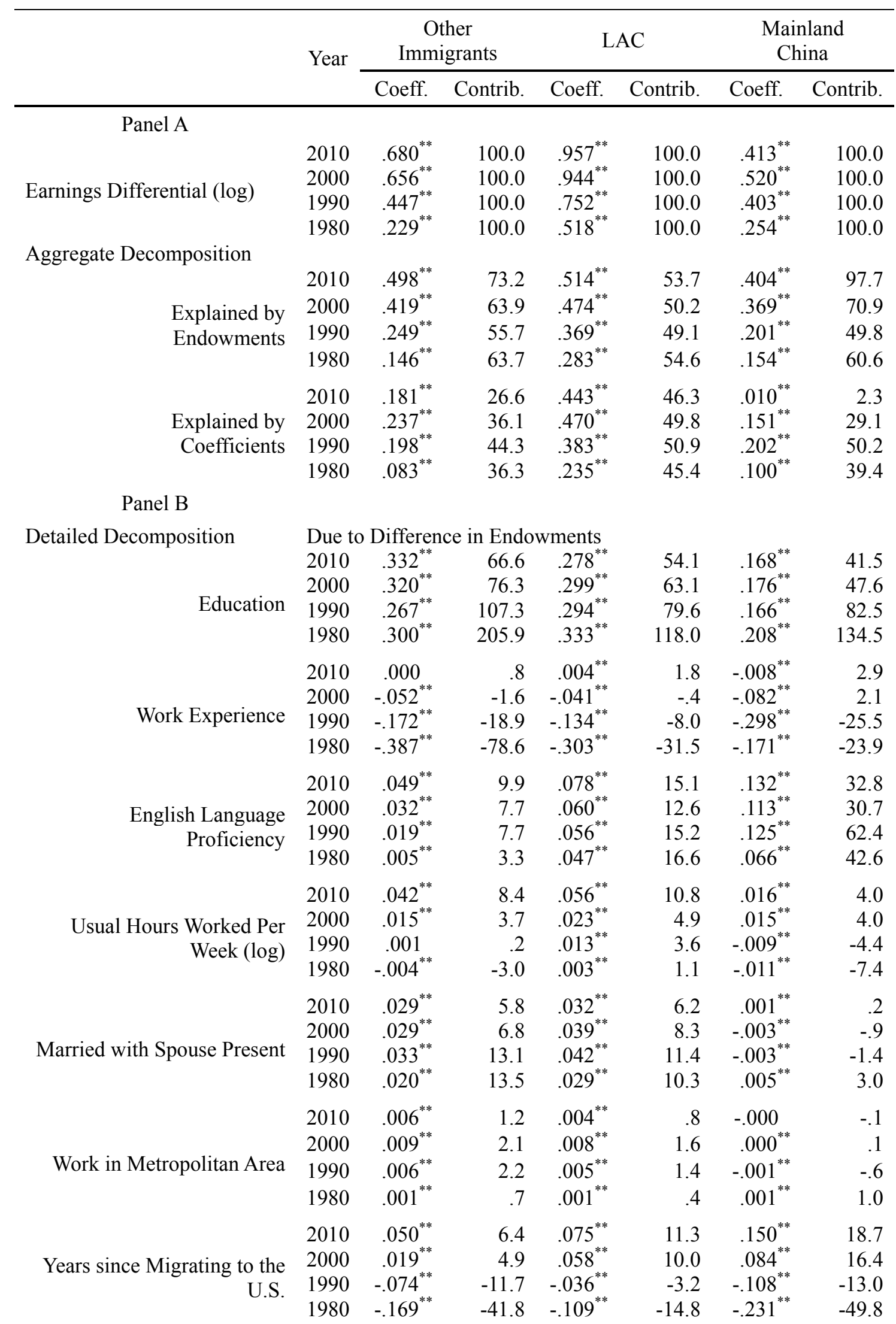




\begin{tabular}{|c|c|c|c|c|c|c|c|}
\hline \multirow[t]{2}{*}{ Detailed Decomposition } & \multicolumn{7}{|c|}{ Due to Difference in Coefficients } \\
\hline & 2010 & $1.150^{* *}$ & 54.4 & $1.658^{* *}$ & 54.9 & $.928^{* *}$ & 32.6 \\
\hline \multirow{3}{*}{ Education } & 2000 & $.714^{* *}$ & 117.7 & $1.118^{* *}$ & 73.2 & $.582^{* *}$ & 57.8 \\
\hline & 1990 & -.005 & -1.5 & $.207^{* *}$ & 21.2 & $.125^{* *}$ & 8.2 \\
\hline & 1980 & $.199^{* *}$ & 48.2 & $.396^{* *}$ & 41.5 & $.231^{* *}$ & 25.4 \\
\hline \multirow{4}{*}{ Work Experience } & 2010 & $.417^{* *}$ & 4.1 & $.442^{* *}$ & 3.6 & $.491^{* *}$ & 5.9 \\
\hline & 2000 & $.168^{* *}$ & 3.9 & $.191^{* *}$ & 3.2 & $.434^{* *}$ & 23.2 \\
\hline & 1990 & $.058^{* *}$ & -8.1 & $.158^{* *}$ & 5.8 & $.402^{* *}$ & 13.5 \\
\hline & 1980 & $-.161^{* *}$ & -38.8 & $-.088^{* *}$ & -10.7 & $.257^{* *}$ & 14.7 \\
\hline \multirow{5}{*}{$\begin{array}{r}\text { English Language } \\
\text { Proficiency }\end{array}$} & 2010 & $.026^{* *}$ & 1.2 & $.049^{* *}$ & 1.6 & $-.093^{* *}$ & -3.3 \\
\hline & 2000 & .022 & 3.5 & $.050^{* *}$ & 3.2 & $-.084^{* *}$ & -8.3 \\
\hline & 1990 & -.010 & -3.3 & $.027^{* *}$ & 2.8 & $-.076^{* *}$ & -5.0 \\
\hline & 1980 & .020 & 4.8 & $.042^{* *}$ & 4.4 & $-.059^{* *}$ & -6.5 \\
\hline & 2010 & $.721^{* *}$ & 34.1 & $1.113^{* *}$ & 36.8 & $1.858^{* *}$ & 65.3 \\
\hline \multirow{3}{*}{$\begin{array}{r}\text { Usual Hours Worked Per } \\
\text { Week (log) }\end{array}$} & 2000 & $-.134^{* *}$ & -22.0 & $.397^{* *}$ & 26.0 & $.401^{* *}$ & 39.8 \\
\hline & 1990 & $.205^{* *}$ & 64.6 & $.624^{* *}$ & 64.2 & $1.258^{* *}$ & 83.1 \\
\hline & 1980 & $.222^{* *}$ & 53.8 & $.517^{* *}$ & 54.2 & $.564^{* *}$ & 62.0 \\
\hline \multirow{4}{*}{ Married with Spouse Present } & 2010 & $-.013^{* *}$ & -.6 & -.001 & .0 & .002 & .1 \\
\hline & 2000 & $-.016^{* *}$ & -2.6 & $-.012^{* *}$ & -.8 & $-.006^{* *}$ & -.6 \\
\hline & 1990 & $.034^{* *}$ & 10.7 & $.042^{* *}$ & 4.3 & $.054^{* *}$ & 3.5 \\
\hline & 1980 & -.001 & -.2 & $.004^{* *}$ & .5 & .003 & .3 \\
\hline \multirow{4}{*}{ Work in Metropolitan Area } & 2010 & -.006 & -.3 & $.021^{* *}$ & .7 & $-.029^{* *}$ & -1.0 \\
\hline & 2000 & $-.023^{* *}$ & -3.8 & -.002 & -.1 & .003 & .3 \\
\hline & 1990 & -.003 & 1.0 & -.010 & -1.0 & $.034^{* *}$ & 2.2 \\
\hline & 1980 & $-.005^{* *}$ & -1.3 & $-.005^{* *}$ & -.6 & $-.004^{* *}$ & -.5 \\
\hline \multirow{4}{*}{$\begin{array}{r}\text { Years since Migrating to the } \\
\text { U.S. }\end{array}$} & 2010 & $.272^{* *}$ & 7.0 & $.224^{* *}$ & 2.4 & $.056^{* *}$ & .5 \\
\hline & 2000 & $.068^{* *}$ & 3.3 & $-.040^{* *}$ & -4.8 & $-.129^{* *}$ & -12.2 \\
\hline & 1990 & $.221^{* *}$ & 36.6 & $.105^{* *}$ & 2.7 & $-.067^{* *}$ & -5.6 \\
\hline & 1980 & $.226^{* *}$ & 33.4 & $.175^{* *}$ & 10.7 & $.102^{* *}$ & 4.6 \\
\hline \multirow{4}{*}{ Observations } & 2010 & \multicolumn{2}{|c|}{84,899} & \multicolumn{2}{|c|}{46,273} & \multicolumn{2}{|c|}{3,796} \\
\hline & 2000 & \multirow{2}{*}{\multicolumn{2}{|c|}{$\begin{array}{l}327,016 \\
196,096\end{array}$}} & \multicolumn{2}{|c|}{182,129} & \multicolumn{2}{|c|}{$\begin{array}{c}11,867 \\
6,788\end{array}$} \\
\hline & 1990 & & & \multirow{2}{*}{\multicolumn{2}{|c|}{$\begin{array}{l}98,875 \\
51,788\end{array}$}} & \multirow{2}{*}{\multicolumn{2}{|c|}{$\begin{array}{l}6,788 \\
3,966\end{array}$}} \\
\hline & 1980 & \multicolumn{2}{|c|}{123,227} & & & & \\
\hline
\end{tabular}

Note: The log of earnings of Taiwanese immigrants in $2010,2000,1990$, and 1980 are $6.401^{* *}, 6.429^{* *}, 6.201^{* *}$, and $5.998^{* *}$, respectively. Observations of Taiwanese immigrants in 2010, 2000, 1990 and 1980 are 866, 3175, 2125 , and 587, respectively. Difference $=\log$ earnings of Taiwanese $-\log$ earnings of other immigrants. ${ }^{* *}$ and ${ }^{*}$ indicate that the estimate is statistically significant at the 5 percent and 10 percent levels, respectively. In the three reference benchmarks of other immigrants, the observations of Taiwanese immigrants are excluded. 
Table 4. Cohort Analysis and Aging Effect

\begin{tabular}{|c|c|c|c|c|c|c|c|c|c|}
\hline & \multirow{2}{*}{$\begin{array}{l}\text { Arrival Cohort } \\
\text { Difference }\end{array}$} & \multicolumn{2}{|c|}{ Taiwan } & \multicolumn{2}{|c|}{$\begin{array}{c}\text { Other } \\
\text { Immigrants }\end{array}$} & \multicolumn{2}{|c|}{$\begin{array}{c}\text { Mainland } \\
\text { China }\end{array}$} & \multicolumn{2}{|c|}{ LAC } \\
\hline & & $\begin{array}{l}\text { Abs. } \\
\text { Earn. }\end{array}$ & $\begin{array}{l}\text { Rel. } \\
\text { Earn. }\end{array}$ & $\begin{array}{l}\text { Abs. } \\
\text { Earn. }\end{array}$ & $\begin{array}{l}\text { Rel. } \\
\text { Earn. }\end{array}$ & $\begin{array}{l}\text { Abs. } \\
\text { Earn. }\end{array}$ & $\begin{array}{l}\text { Rel. } \\
\text { Earn. }\end{array}$ & $\begin{array}{l}\text { Abs. } \\
\text { Earn. }\end{array}$ & $\begin{array}{l}\text { Rel. } \\
\text { Earn. }\end{array}$ \\
\hline \multirow{3}{*}{$\begin{array}{l}\text { Cross } \\
\text { Section } \\
\text { Growth }\end{array}$} & 1990-99 minus 2000-09 & $.106^{* *}$ & $.123^{* *}$ & $.240^{* *}$ & $.235^{* *}$ & $.385^{* *}$ & $.356^{* *}$ & $.238^{* *}$ & $.233^{* *}$ \\
\hline & 1980-89 minus $1990-99$ & $.304^{* *}$ & $.302^{* *}$ & $.141^{* *}$ & $.227^{* *}$ & $.156^{* *}$ & $.142^{* *}$ & $.215^{* *}$ & $.318^{* *}$ \\
\hline & 1970-79 minus $1980-89$ & $.428^{* *}$ & $.371^{* *}$ & $.234^{* *}$ & $.211^{* *}$ & $.138^{* *}$ & $.117^{* *}$ & $.201^{* *}$ & $.190^{* *}$ \\
\hline \multirow{3}{*}{$\begin{array}{l}\text { Within } \\
\text { Cohort } \\
\text { Growth }\end{array}$} & 1990-99 minus 2000-09 & $.107^{* *}$ & $.152^{* *}$ & $.174^{* *}$ & $.241^{* *}$ & $.328^{* *}$ & $.369^{* *}$ & $.204^{* *}$ & $.271^{* *}$ \\
\hline & 1980-89 minus $1990-99$ & $.418^{* *}$ & $.343^{* *}$ & $.084^{* *}$ & $.169^{* *}$ & $.410^{* *}$ & $.336^{* *}$ & $.097^{* *}$ & $.197^{* *}$ \\
\hline & 1970-79 minus $1980-89$ & $.611^{* *}$ & $.271^{* *}$ & $.101^{* *}$ & $.103^{* *}$ & $.159^{* *}$ & $.086^{* *}$ & $.098^{* *}$ & $.108^{* *}$ \\
\hline \multirow{3}{*}{$\begin{array}{l}\text { Across } \\
\text { Cohort } \\
\text { Growth }\end{array}$} & 1990-99 minus 2000-09 & -.001 & $-.029^{* *}$ & $.066^{* *}$ & $-.006^{* *}$ & $.057^{* *}$ & $-.013^{* *}$ & .034 & $-.038^{* *}$ \\
\hline & $1980-89$ minus $1990-99$ & $-.114^{* *}$ & $-.041^{* *}$ & $.056^{* *}$ & $.058^{* *}$ & $-.254^{* *}$ & $-.195^{* *}$ & $.119^{* *}$ & $.121^{* *}$ \\
\hline & 1970-79 minus $1980-89$ & $-.183^{* *}$ & $.100^{* *}$ & $.133^{* *}$ & $.109^{* *}$ & $-.021^{* *}$ & $.031^{* *}$ & $.103^{* *}$ & $.082^{* *}$ \\
\hline \multirow{2}{*}{$\begin{array}{l}\text { Aging } \\
\text { Effect }\end{array}$} & 1990-99 & \multicolumn{2}{|c|}{$-.051^{* *}$} & \multicolumn{2}{|c|}{$-.028^{* *}$} & \multicolumn{2}{|c|}{$-.211^{* *}$} & \multicolumn{2}{|c|}{$-.021^{* *}$} \\
\hline & $\begin{array}{l}1980-89 \\
1970-79 \\
\end{array}$ & \multicolumn{2}{|c|}{$\begin{array}{l}-.023^{* *} \\
-.035^{* *}\end{array}$} & \multicolumn{2}{|c|}{$\begin{array}{l}-.033^{* *} \\
-.068^{* *}\end{array}$} & \multicolumn{2}{|c|}{$\begin{array}{l}-.203^{* *} \\
-.181^{* *}\end{array}$} & \multicolumn{2}{|c|}{$\begin{array}{l}-.045^{* *} \\
-.128^{* *}\end{array}$} \\
\hline
\end{tabular}

Note: ${ }^{* *}$ and ${ }^{*}$ indicate that the estimate is statistically significant at the 10 percent and 5 percent levels. The aging effects are computed from the 5 percent 2000 Census. 

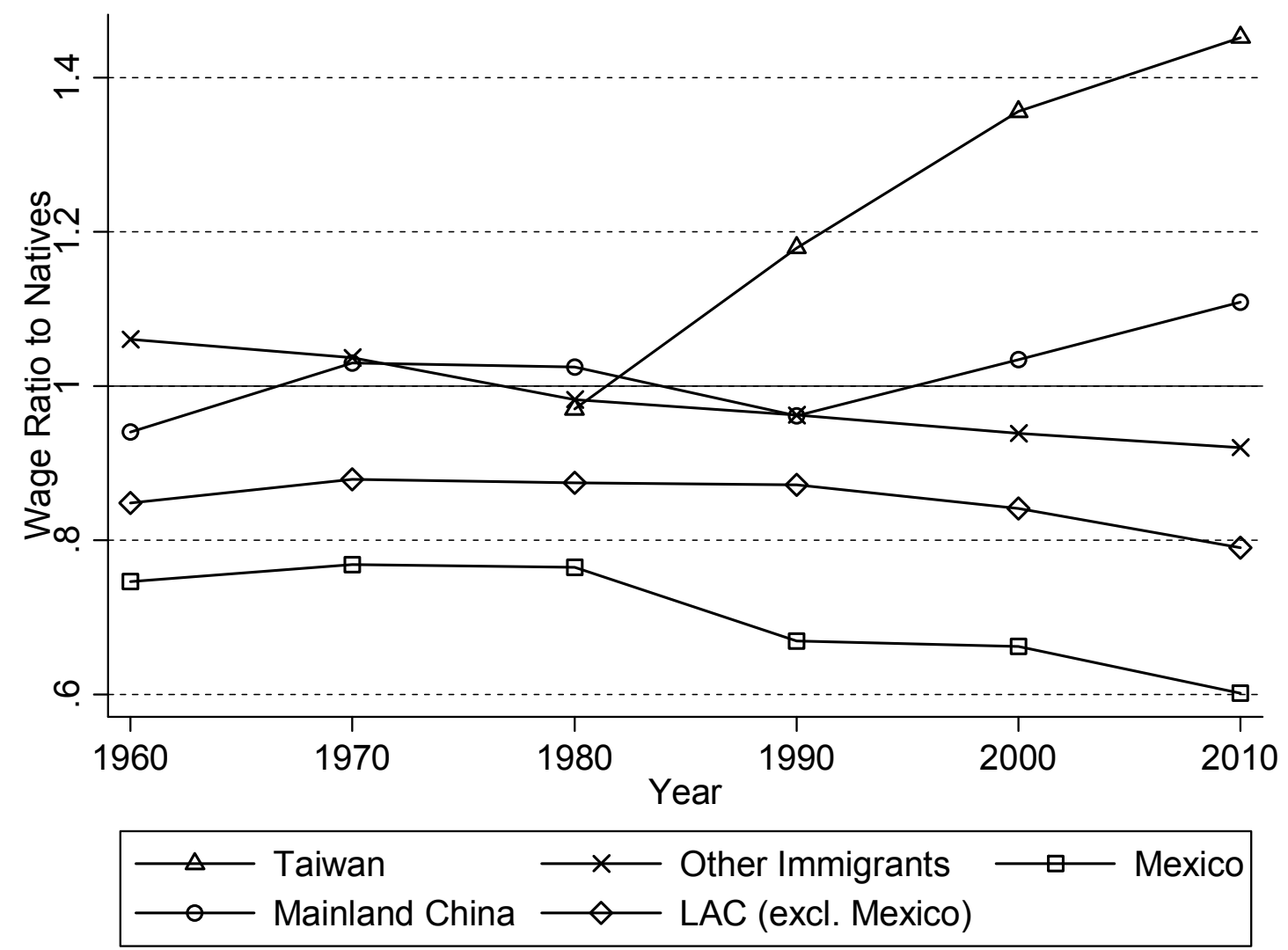

Figure 1. Wage Ratios to Natives, by Taiwanese and Select Immigrant Groups Note: The first U.S. census to include Taiwan as the birth place was in 1980. The data are drawn from 1 percent 1960, 1970 and 5 percent 1980, 1990, 2000 U.S. Censuses and 2010 ACS. 